\title{
The Role of Nurse in the Form of Palliative Care on the Quality of Life of Patients with Cervical Cancer
}

\author{
Rita Kirana $^{1 \text { (corresponding author) }}$, Tut Barkinah ${ }^{2}$, Vonny Khresna Dewi ${ }^{3}$ \\ ${ }^{1}$ Poltekkes Kemenkes Banjarmasin, Indonesia; ritakirana321@ gmail.com \\ ${ }^{2}$ Poltekkes Kemenkes Banjarmasin, Indonesia; tutbarkinah@ymail.com \\ ${ }^{3}$ Poltekkes Kemenkes Banjarmasin, Indonesia; vonnykdfkm@gmail.com
}

Submitted: January 7, 2020 -Revised: February 11, 2020 -Accepted: February 12, 2020 -Published: February 28, 2020

\begin{abstract}
The diagnosis of cervical cancer has become a big burden for both patients and families. Most patients with advanced stage cancer have a low quality of life score which indicates they have a problem. while the family may not be ready to carry out its role in the quality of life of patients with cervical cancer. The objective of this research was to identify the correlation of nurse support in the form of palliative care on the quality of life of patients with cervical cancer. This research employed cross-sectional design. Population in this research was all patients with cervical cancer in gynecology ward in Banjarmasin. Participant for this research were patients with cervical cancer and nurses. Data were taken by structured interview and task question form. Linear regression analysis was applied with level of significance $\leq 0.05$. The results shown that most nurses ha good level of their role in the form of palliative care while most patients also have moderate level of quality of life. Also there are significance correlations of nurse role in the form of palliative care on the quality of life of patients with cervical cancer.
\end{abstract}

Keywords: cervical cancer; quality of life; palliative care; nurse; role

\section{INTRODUCTION}

Cancer is one of the non-communicable diseases which is the main cause of death in the whole world. The latest report released by the International Agency for Research on Cancer, the World Health Organization (WHO) estimates that there are 18.1 million new cancer cases and 9.6 million deaths that occurred in 2018 and will increase significantly to around 13.1 million deaths in $2030^{(1)}$. So is the case in Indonesia, based on the Indonesian Ministry of Health's Data and Information Center (InfoDATIN) report in 2012 that there were around 8.2 million deaths caused by cancer. Cancer prevalence in Indonesia according to Riskesdas in 2013 was $1.4 \%$ or around 347,792 people had cancer ${ }^{(2)}$.

The highest cancers that occur in women in Indonesia are breast cancer and cervical cancer. Every year no less than 15,000 cases of cervical cancer occur in Indonesia. That makes cervical cancer called the number 1 female killer in Indonesia. The label is not excessive because every day in Indonesia out of 40 women diagnosed with cervical cancer, 20 of them died of cervical cancer. The high number of cervical cancer cases in Indonesia makes WHO put Indonesia as the country with the highest number of cervical cancer sufferers in the world ${ }^{(3)}$.

Province of D.I. Yogyakarta ranks the highest prevalence of cervical cancer, which is 2.4\%o. Meanwhile in terms of number of sufferers, the provinces of Central Java and East Java are still the top provinces with the highest number of cervical, breast and prostate cancer cases in Indonesia. The prevalence results also show that South Kalimantan is ranked 11th for cancer, which is $1.6 \%$ or around 6,145 people. Based on the results of the estimation of the number of cancer patients in East Kalimantan Province was ranked first, which is $1.7 \%$, or estimated at about 7,645 people in the past and second place in the South Kalimantan province ${ }^{(2)}$.

Meanwhile, the treatment of cancer has been using surgical methods, radiotherapy and chemotherapy. The radiotherapy devices themselves in Indonesia only have around 28 units. Very far from its ideal condition, which is 1 tool for 1 million inhabitants, with an Indonesian population of nearly 250 million, at least we need 250 radiotherapy devices. The price of 1 radiotherapy device is around Rp. 15 billion, quite expensive. The spread is not evenly distributed on all islands in Indonesia. Most are in Java and Sumatra. The disease is very concerned in its handling by nurses in Indonesia. Most Indonesian nurses are confused in giving nursing care to patients with terminal illness and how to deal with abandoned families. Nurses are trained for these problems, it's just that sometimes the hospital policy prevents their desire to help patients more.

Such reasons have caused the Indonesian government to establish policies related to improving the quality of health services for patients in Indonesia. In 2007 the Minister of Health of the Republic of Indonesia issued a Decree Number 812 / MENKES / SK / VII / 2007 concerning Palliative Care Policy. The contents are nurses who are assigned to carry out a palliative care for patients with terminal diseases that may not be able to recover and have been declared dead. The purpose of this palliative care is that patients with terminal illness can die 
peacefully. Nurses are also required to help families left by patients to accept and not experience ongoing depression. According to the Palliative Care Quality Network report, cancer is the highest rate of palliative care, which is $30.0 \%{ }^{(4)}$.

Palliative care is a continuous health service that aims to improve the quality of life, reduce patient complaints, provide spiritual and psychosocial support given from the diagnosis to the end of life. Early palliative care can reduce unnecessary use of health services or hospital care ${ }^{(5)}$. Palliative care is an approach that aims to improve the quality of life of patients and calm families who face problems related to lifethreatening diseases ${ }^{(6)}$. While quality of life has become an important topic in terms of medical care, because quality of life can decrease when individuals are exposed to illness and illness for a long time ${ }^{(7,8)}$. Some other experts also state that a low quality of life is not always synonymous with low health, some patients effectively adjust to their illness, handle it well and achieve their goals and objectives ${ }^{(9)}$.

In other words, this palliative care demands the role of nurses in it. As is known, the role of nurses is very important because this role helps clients regain their health through a process of care. The treatment process is not only cured of certain diseases, but with the skills possessed by nurses, the role of nurses is able to improve physical health, and restore emotional and spiritual ${ }^{(10)}$. The role of implementing nurses can provide nursing care directly or indirectly to patients and families well, skillfully, safely, quickly, and precisely to improve the patient's health status.

Phenomenon in the field still excludes the tendency of nurses still not carrying out their role in providing nursing care to clients that have an impact on the quality of life of patients in chronic diseases. Rumintang research results ${ }^{(11)}$ stated the implementation of the role of nurses in providing nursing care is still far from the standard of professional nursing care and palliative care and is still minimal by nurses. Based on the description above, the authors are interested in conducting research to determine the relationship of the role of nurses to the quality of life of patients with cervical cancer who undergo palliative care at Ulin Hospital Banjarmasin

\section{METHODS}

This research used descriptive analytical research method with cross sectional design, where data relating to independent and bound variables will be collected at the same time ${ }^{(12)}$. This research was conducted in Ulin Hospital Banjarmasin in 2018. The population in this study targeted all nurses and patients with cervical cancer in Ulin Banjarmasin. The sample in this study were 30 patients with cervical cancer and 30 nurses. The inclusion criteria were cervical cancer patients undergoing palliative care, patients who can work independently or assisted, nurses who are in palliative care with a minimum of Nursing D3 education, as well as nurses and patients who are willing to become respondents. The exclusion criteria were patients who have decreased consciousness and nurses who are on leave, permission, and sick. Data collection was done by distributing questionnaires consisting of questionnaires on the role of nurses as care giver and quality of life questionnaire (KDQOL version 1.3). Data were analyzed using Spearman correlation test.

\section{RESULTS}

\section{The Nurse Role in Palliative Care of Cervical Cancer Patients}

Based on Table 1 indicates that the picture of the nurse role in palliative care of cervical cancer patients was in the good category $(87 \%)$.

Table 1. The distribution of nurse role in palliative care of cervical cancer patients

\begin{tabular}{|c|c|c|}
\hline Role of nurse & Frequency & Percentage \\
\hline Good & 26 & 87 \\
\hline Does not good & 4 & 13 \\
\hline
\end{tabular}

\section{The Quality of Life of Patients with Cervical Cancer}

Based on Table 2 it can be seen that the quality of life of patients with cervical cancer was in moderate category $(47.1 \%)$. 
Table 2. The distribution of quality of life of cervical cancer patients

\begin{tabular}{|c|c|c|}
\hline Quality of life of patients & Frequency & Percentage \\
\hline Low & 13 & 38.2 \\
\hline Moderate & 16 & 47.1 \\
\hline High & 5 & 14.7 \\
\hline
\end{tabular}

\section{The Relationship between Nurse Role in Palliative Care with Quality of Life of Patients with Cervical Cancer}

Analysis of the relationship between the role of nurses and the quality of life of patients with cervical cancer who underwent palliative care was measured using the Spearman correlation test.

Table 3 Relationship of nurse role in palliative care on quality of life of patients with cervical cancer

\begin{tabular}{|l|c|c|}
\hline \multicolumn{1}{|c|}{ Variables } & $\mathrm{r}$ & $\mathrm{p}$-value \\
\cline { 1 - 1 } Nurse role in palliative care & 0.647 & 0.000 \\
\cline { 1 - 1 } Quality of life of patients & & \\
\hline
\end{tabular}

Data analysis was performed by Spearman rho correlation test obtained correlation coefficient (r) of 0.647 with p-value of $0.000(<0.05)$. This shows that there was a significant relationship between the role of nurses with quality of life patients with cervical cancer who undergo palliative care with the strength of moderate and positive relationships, in the sense that the higher the role of nurses the higher the quality of life of patients with cervical cancer undergoing palliative care at Ulin Hospital Banjarmasin.

\section{DISCUSSION}

The results of research on the role of nurses with the quality of life of patients with cervical cancer who are undergoing palliative care at Ulin Hospital Banjarmasin are 26 people as good as many as (87\%). The results of the study of the role of nurses with the quality of life of patients with cervical cancer who underwent palliative care were positively related to the interpretation of the value of the strength of the moderate relationship. Its mean, there is a relationship between the role of nurses and the quality of life of patients with cervical cancer who undergo palliative care at Ulin Hospital Banjarmasin. According to researchers, it can be happened because the role of nurses is able to improve physical health, and restore emotional and spiritual patients. This process makes a patient get health services, namely a series of decisions and events that are involved in interactions between a number of people, including family, friends, and professionals who provide health care services. The results of this study in line with the goal of palliative care in cancer patients is to improve quality of life and deliver patients with End of life conditions calmly. This is also complies with the technical guidelines for palliative cancer services, palliative care in cancer patients is an integrated service by the palliative team, one of whom is nurse to improve the quality of life of patients and provide support for families who face problems related to the patient's condition.

The thing that can be done by nurses to improve the quality of people living with cancer, among others, is to have basic skills in treating cancer patients who generally have difficulty carrying out daily activities, one of which is by taking palliative training to treat cancer sufferers. The ability referred to here is the ability to understand and provide good nutrition needed by cancer sufferers so that their conditions are met, understand how to move, turn patients upside down and even bathe them, provide anti-pain medication and provide medicines to cancer patients according to the doctor's prescription, provide psychosocial or spiritual support with counseling and effective communication. Meanwhile, to measure it must refer to the Palliative Care Guidelines issued by the NCP (2013), namely by looking at the Structure and Process of Care, physical aspects in care, psychological and psychiatric aspects in care, social aspects in care, spiritual, religious, and existential aspects in care, cultural aspects of care, end of life care and legal and ethical aspects of care. In addition, the measurement of palliative care can be done by looking at the results of evaluations of patients or families, including: Pain and other symptoms resolved well, stressed patients and families are reduced, Feeling has the ability to control existing conditions, reduced family burden, Relationship with others are better, Quality of life improves and Patients feel the meaning of life and grow spiritually.

The results of Sapri's research ${ }^{(13)}$ stated that the involvement of health personnel is needed by patients, especially in providing nursing care, information for patients and families, and subsequent treatment plans. The 
involvement of health workers with patients can be in the form of supervision, the closeness of emotional relationships will affect patient compliance in carrying out care. This is also reinforced by Lubis's ${ }^{(14)}$ study, which stated that medical personnel such as doctors and nurses who faced directly with patients $36 \%$ were the most active sources of social support.

In addition, according to Stuart ${ }^{(15)}$ nurses who are concerned with biological, psychological, and sociocultural needs of clients, see human experience in a broad range. They must learn to overcome anxiety, anger, sadness and joy, in helping clients throughout the range of illnesses. Nurses must also be able to build positive perspectives on patients with cervical cancer in order to improve their quality of life as revealed by Efklides and Moratiou (16) "The perspective adopted from positive psychology, with positive aspects of development such as capabilities and assets that lead to good adaptation and ultimately enhance the quality of life in every stage of their lives." Nurses have an important role in providing support for cancer patients in dealing with symptoms that are experienced ${ }^{(17)}$.

In other words, the act of nurses in improving the quality of life of patients with cervical cancer who undergo palliative care at RSUD Ulin Banjarmasin is to give confidence to patients, provide support or enthusiasm to patients, provide an explanation of the benefits of doing palliative care for their health, and provide mental support. Nurses can perform nursing actions by stimulating awareness and acceptance of problems or health needs for patients by supporting healthy attitudes or emotions in dealing with these problems.

Of all these roles, nurses in Ulin Hospital have carried out their roles well and are able to improve the quality of life of patients and provide support for families who face problems related to the patient's condition.

\section{CONCLUSION}

Based on the results of research and discussion on the relationship of the role of nurses with the quality of life of patients with cervical cancer who undergo palliative care, it can be concluded that; the role of nurses in the good category, quality of life of patients with cervical cancer who in palliative care in the moderate category, and there is a relationship between the role of nurses with quality of life patients with cervical cancer who are in palliative care at Ulin Banjarmasin Hospital which means that the better the role of nurses will be higher quality of life of patients with cervical cancer who are in palliative care at Ulin Hospital Banjarmasin.

This study recommends that nurses and health care institutions, especially central and local governments, increase nurse involvement in health care for cervical cancer patients by providing appropriate skills information and training specifically related to palliative care.

Further research should use more appropriate instruments for respondents with Indonesian culture and language to facilitate and improve the validity of measurements of nurse role variables and also the measurement of the quality of life of cervical cancer patients. In addition, it can also add other variables as factors that determine the role of nurses in palliative care.

\section{REFERENCES}

1. CNN, WHO. Cancer Kills Nearly 10 Million People in the World This Year (Kanker Membunuh Hampir 10 Juta Orang di Dunia Tahun Ini) [Internet]. 2018. Available from: https://www.cnnindonesia.com/gayahidup/20180913133914-255-329910/who-kanker-membunuh-hampir-10-juta-orang-di-dunia-tahun-ini.

2. Ministry of Health of RI. Infodatin: Cancer Situation (Situasi Penyakit Kanker). Jakarta: Pusdatin, MoHRI; 2018.

3. Anggraeni DR. The number of cancer patients in Indonesia is increasing every year (Jumlah Penderita kanker di Indonesia tiap tahun makin meningkat) [Internet]. Available from: https://artikel.allianz.co.id/detail-article/Jumlah-Penderita-Kanker-Di-Indonesia-3817.

4. PCQN. Palliative Care Quality Network [Internet]. 2017 [cited 2019 Dec 17]. Available from: https://www.pcqn.org

5. WHO. Definition of Palliative Care [Internet]. WHO. Available from: http://www.who.int/cancer/palliative/definition/en/

6. MoH-RI. KEPMENKES RI No: 812 / MENKES / SK / VII / 2007 concerning Palliative Care Policies (KEPMENKES RI No: 812/MENKES/SK/VII/2007 Tentang Kebijakan Perawatan Palliative) Jakarta: MoH-RI; 2017.

7. Sarafino EP, Smith TW. Health psychology: Biopsychosocial interactions (7th ed). USA: John Wiley \& Sons, Inc; 2011.

8. Siregar AR, Muslimah RN. Picture of quality of life in early adult women with breast cancer (Gambaran kualitas hidup pada wanita dewasa awal penderita kanker payudara). Psikologia. 2014;9(3):82-88.

9. Pawlak BS, Pazdrowska AD, Rzepa B, Szewczyk A, Przytocka AS, Zaba R. Health-related quality of life, 
optimism, and coping strategies in persons suffering from localized scleroderma. Psychology, Health \& Medicine. 2013;18(6):654-663.

10. Perry, Potter. Nursing Fundamental Textbooks - Concepts, Processes and Practices (Buku Ajar Fundamental Keperawatan-Konsep, Proses, dan Praktik). Jakarta: EGC; 2004.

11. Wahyuni AS. Relationship between Caring Implementation for Nurses and Satisfaction of Haji Adam Malik Hospital Medan (Hubungan Pelaksanaan Caring pada Perawat dengan kepuasaan pasien rawat Inap RS Haji Adam Malik Medan. Medan: USU; 2008.

12. Setiadi. The concept and practice of writing nursing research (Konsep dan praktek penulisan riset keperawatan). Yogyakarta: Graha Ilmu; 2013.

13. Sapri A. Chronic Kidney Failure Care, Factors Influencing Compliance in Reducing Fluid Intake in Chronic Kidney Failure Underwent Hemodialysis at RSUD Dr. H. Abdul Moeloek Bandar Lampung (Asuhan Gagal Ginjal Kronik, Faktor-faktor yang Mempengaruhi Kepatuhan dalam Mengurangi Asupan Cairan pada Gagal Ginjal Kronik yang Menjalani Hemodialisa di RSUD Dr. H. Abdul Moeloek Bandar Lampung) [Internet]. 2008. [cited 2019 Dec 17].

14. Lubis AJ. Social Support of Terminal Kidney Failure Patients Following Hemodialysis Therapy (Dukungan Sosial Pasien Gagal Ginjal Terminal yang Melakukan Terapi Hemodialisa). Medan: FK-USU; 2006.

15. Stuart GW. Ethics and advocacy in psychiatric nursing practice. Indian J Psy Nsg. 2016;11:44-8.

16. Efklides A, Moraitou D. Introduction: Looking at quality of life and well-being from a positive psychology perspective. In Efklides A, Moraitou D (Eds.). Social indicators research series. Vol. 51. A positive psychology perspective on quality of life. 2013.

17. Mackenzie J, Mac Callam J. Preparing staff to provide bereavement support.Palliative nursing. 2009;2(3):22. 